\title{
The Role of The Muslim Family in Dealing with Adolescent Out-of-Wedlock Pregnancy
}

\author{
Salasiah Hanin Hamjah \\ Universiti Kebangsaan Malaysia \\ Email: salhanin@ukm.edu.my
}

\section{Rosmawati Mohamad Rasit}

Universiti Kebangsaan Malaysia

Email: rosmawati@ukm.edu.my

Mohd. Al-Adib Samuri

Universiti Kebangsaan Malaysia

Email: al_adib@ukm.edu.my

Fariza Md. Sham

Universiti Kebangsaan Malaysia

Email: farisham@ukm.edu.my

Zainab Ismail

Universiti Kebangsaan Malaysia

Email: zainab@ukm.edu.my

Zuliza Mohd Kusrin

Universiti Kebangsaan Malaysia

Email: zuli@ukm.edu.my

\section{Doi:10.5901/mjss.2014.v5n29p101}

\section{Abstract}

There are various factors which contribute to adolescent out-of-wedlock pregnancy such as family, peers, media, education and environment. Factors which stem from the family include problems associated with lack of love and affection, parents who are too busy with work, divorce and domestic crisis. Nevertheless, the family is identified as a small institution which has an important role in curbing this problem. In relation to this, the need for a detailed study to identify the factors contributing to adolescent out-of-wedlock pregnancy in terms of the family and the role which it can play to curb this problem is very important to overcome this social ill and prevent it from worsening into a chronic social issue. This study is designed as a survey study. 50 respondents have been selected as sample study in two adolescent shelter homes in Malaysia, namely, Raudhatus Sakinah and PERKID by using the method of convenience sampling. Data obtained are descriptively analysed using software SPSS 20.0. Study findings show that out-of-wedlock pregnancy among Muslim adolescents is caused by the failure of parents to control their daughters' behaviour as well as by a communication problem between parents and their adolescents. Findings also show that the family institution can play a role in overcoming this social ill through parents being exemplary role-models, giving their children adequate religious education, monitoring their children's movements, getting advisory and guidance services from family and religious counselors in educating their children and getting closer to them.

Keywords: out-of-wedlock pregnancy; adolescents; family; religious education;

\section{Introduction}

Various parties including family, school, society and state play their respective roles in overcoming the problem of out-ofwedlock pregnancy among adolescents. For example, the school has launched a 'hate zina (fornication)' campaign to 
curb this social ill. The relevant authorities such as anti-vice officers carry out their tasks in arresting adolescents who are in close proximity or commit fornication. Nevertheless, it is the family which is found to be more effective in containing this social ill because education begins early at home. With this realization, this study is conducted with the purpose of examining the role of the family to overcome out-of-wedlock pregnancy among adolescents.

Literally, out-of-wedlock pregnancy may be defined as pregnancy through sexual relations between a couple who are not legally married to each other (Alavi et al., 2012). In Malaysia, more than 300 Malay children and adolescents between the age of 13 and 25 have been found to commit sexual misconduct and free sex causing pregnancy and also abortion (Sarnon et al., 2012). A survey study through a questionnaire by New Straits Times Youth Quake in April 2002 for 200 adolescents between the age of 15 and 19 years showed that 44\%t had sexual relations at least once (Yaakob, 2005), and according to a 2004 report of Durex Global Sex Survey, the average age for Malaysians to have sex is 19 years (Mahadi, 2011). Many factors have contributed to adolescents being exposed to the problem of out-of-wedlock pregnancy, such as fornication, free sex, free mingling, family problems, environment, peers and the media influence (Mohd Syamil \& Adriana Balqis, 2010; Ali Mohamed \& Sardar Baig, 2010; Dev Raj et al., 2010; Moore 2001; Weisz \& Earls 1995; Brandt et al., 1978). A study by Sarnon et al. (2012) found that among the contributory factors was free sex. Jaudin \& Shamsudin (1995) and Purusothaman (1997) concluded that one contributory factor was having a boyfriend. Jaudin \& Shamsudin (1995) also found that adolescents who did not receive attention from parents and who watched pornography were prone to this social ill. In addition, Alavi et al., (2012) found other factors like not having a close relationship with parents, residential environment, influence of peers and exposure to widespread sexual activity in the internet network. A study by Abd. Ghadur and Abdul Kadir (2009) found other contributory factors such as parental divorce, too many siblings and re-marriage of the mother to a low-income man.

Past studies have found several factors which cause this social ill such as free sex, free mingling, having a boyfriend, influence of media, influence of peers, and family problems such as lack of parental attention and want of closeness to parents. The results show that family is one of the contributory factors for this social ill. Hence, this study is conducted to ascertain the family aspect which contributes to out-of-wedlock pregnancy among adolescents and to analyse the role of the family in overcoming this social ill.

\section{Research Objectives}

- To identify the family aspect as a factor contributing to out-of-wedlock pregnancy among adolescents.

- To analyse the role of the Muslim family in overcoming the problem of adolescent out-of-wedlock pregnancy.

\section{Research Methodology}

This reseach is quantitative in design using the survey study method. Questionnaire forms were used to collect data. Respondents in this research comprised of 50 unmarried pregnant adolescents in the care of two shelter homes, 23 persons in PERKID and 27 in Raudhatus Sakinah. Selection of respondents was through convenience sampling. A pioneer study was conducted to evaluate reliability by the method of internal consistency using alpha cronbach coefficient.

By this method, each research variable has been tested for its alpha cronbach value (Table 1). On the whole, the alpha cronbach value obtained for each construct is in the index range of 0.746 to 0.920 (Table 2). This item reliability value is good and acceptable according to what is discussed by Gliem \& Gliem (2003) and Petterson et al. (2004). As the alpha cronbach value for all variables exceed 0.7, the research instrument has acceptable internal consistency and reliability. The data obtained from the questionnaire forms are analysed and presented in the form of percentage, frequency and mean.

Table 1. Alpha Cronbach value (a) of Adolescent Out-of-Wedlock Pregnancy Variable Factors

\begin{tabular}{clc}
\hline No. & Variable & Alpha Cronbach value $(\mathrm{a})$ \\
\hline 1 & Parental Factor & 0.854 \\
2 & Peer Factor & 0.746 \\
3 & Mass Media Factor & 0.920 \\
4 & Own Personal Factor & 0.785 \\
\hline
\end{tabular}


Table 2. Alpha Cronbach Value(a) of Research Variable

\begin{tabular}{clc}
\hline No. & Variable & Alpha Cronbach Value (a) \\
\hline 1 & Out-of-wedlock Pregnancy & 0.925 \\
\hline
\end{tabular}

\section{Research Results and Discussion}

This research is conducted in order to identify the family factor as one of the causes contributing to out-of-wedlock pregnancy among adolescents. Mean analysis finds that the item "Communication level between my parents and myself is low in terms of problem-sharing" has the highest mean value (mean=2.60) exceeding other items, followed by the next highest item "My parents have a high level of trust in me for activities out of home" (mean=2.50) and "Parents' preoccupation with work leaves for me little attention and oversight" (mean=2.40).

Further, a number of respondents admitted that "Domestic crisis has led me to leave home and socialize ' (mean= 2.20)., "Parents neglect to emphasize or inculcate religious education in my life" (mean=1.90), "Parents are not worried about my mixing with men" (mean=1.80), "I am exposed to free sex by family members" (mean=1.60) and "Parents expelled me from home when I got pregnant"(mean=1.50).

Research findings which show that the item "Communication level between my parents and myself is low in terms of problem-sharing" (mean=2.60) clearly reflect that communication within the family is very important to avoid children being drawn into chronic social ills. This finding is in line with that by Alavi et al., (2012) who also found that among the factors contributing to out-of-wedlock pregnancy is the absence of closeness between adolescents and parents. This finding explains that parents constitute one of the factors for out-of-wedlock pregnancy. Poor relations with parents cause adolescents not to refer or share problems with them.

Research results also show that parents who are too preoccupied with work cause adolescents to feel neglected for want of attention and oversight. (mean=2.40). Being too busy has forced parents to trust adolescents in their activities outside home (mean=2.50) without realizing that the freedom given endangers the welfare of adolescents and exposes them to the social ill of free mixing unmonitored by parents (mean=2.40).

Results also show that domestic crisis causes adolescents to make the decision to leave home and socialize (mean=2.20). This decision is made by the adolescent herself/himself as she/he can no longer face the stress of domestic crisis within the home and assumes that outside of the home she/he may avoid the crisis and be free to socialize without parental control. However, among the respondents are those who have been thrown out of home by the family after their pregnancy was discovered (mean $=1.50$ ). This happens because parents feel shameful as out-ofwedlock pregnancy is not acceptable by local society. This finding is supported by a similar finding in a study by Sarnon et al. (2012) which found that parents are inclined to send their pregnant adolescents to shelter homes with the hope that the shame will remain hidden as the social stigma for families with out-of-wedlock pregnancy is very severe.

Lack of adequate religious education provided by parents (mean=1.90) with an attitude of indifference to the issue of daughters mixing freely with males (mean=1.80) also contributes to out-of-wedlock pregnancy among adolescents. In this context, adolescents are not exposed to information on the prohibition against free mixing between males and females, and encouraged by the indifferent attitude of parents adolescents become increasingly encouraged to indulge in their desires to the extent of committing fornication and ending up pregnant out-of-wedlock. Worse than this, among these adolescents are those who have the problem of being exposed to free sex behaviour by family members such as their own sisters, brothers, mother or father (mean=1.60). This increasingly hastens the moral decay of such adolescents towards free mixing, fornication and out-of-wedlock pregnancy.

The above discussion clearly shows that lack of adequate religious education in the family will lead to breaching of religious laws such as free mixing, free sex, fornication and negligence of the responsibility to inculcate moral values in children. 
Table 3. Parental Factor

\begin{tabular}{|c|c|c|c|c|c|}
\hline No. Parental Factor & Strongly disagree & Dis-agree & Agree & Strongly agree & Mean \\
\hline $\begin{array}{l}\text { Parents'preoccupation with work leaves for me little attention and } \\
\text { oversight. }\end{array}$ & $8(16 \%)$ & $20(40 \%)$ & $18(36 \%)$ & $4(8 \%)$ & 2.40 \\
\hline 2 Parents place a lot of trust in me for my activities outside of home. & $7(14 \%)$ & $16(32 \%)$ & $22(44 \%)$ & $5(10 \%)$ & 2.50 \\
\hline $\begin{array}{l}3 \text { Level of communication between parents and me is low on problem- } \\
\text { sharing. }\end{array}$ & $10(20 \%)$ & $10(20 \%)$ & $19(38 \%)$ & $11(22 \%)$ & 2.60 \\
\hline 4 Parents threw me out from home on discovering my pregnancy. & & & & & \\
\hline 5 Parents are indifferent to my mixing with males. & $19(38 \%)$ & $23(46 \%)$ & $6(12 \%)$ & $2(4$ & 1.80 \\
\hline 6 Parents do not emphasize or inculcate religious educa & & & $11(2$ & & \\
\hline 7 Domestic crisis led to & $20(40 \%)$ & $9(18 \%)$ & $13(26 \%)$ & $8(16 \%)$ & 2.20 \\
\hline 8 I am exposed to free sex behavior by other family members. & $27(54 \%)$ & $16(32 \%)$ & $5(10 \%)$ & $2(4 \%)$ & 1.60 \\
\hline
\end{tabular}

\section{Source: Questionnaire UKM-PP-05-FRGS0223-2010}

Research results also find that respondents have certain expectations of their family in overcoming this problem. This can be the guideline for the role of the Muslim family in handling the problem of pregnant but unmarried adolescents. Mean analysis finds the item "In my view, parents should be exemplary role models" scores the highest (mean=3.60), followed by item" In my view, parents need to provide religious education for their children" (mean=3.40) and item "In my view, parents need to monitor their children's movements" (mean=3.40). The item with the lowest value in the mean analysis is "In my view, parents need to treat their adult children as friends" (mean=3.30) and "In my view, parents should get advisory and counseling services from family and religious experts in educating their children" (mean=3.30).

Table 4. Role of Family Institution

\begin{tabular}{|c|c|c|c|c|c|}
\hline No. Family Institution & Strongly disagree & Disagree & Agree & Strongly agre & e Mean \\
\hline $\begin{array}{l}1 \text { In my view, parents need to provide religious education for their } \\
\text { children. }\end{array}$ & $2(4 \%)$ & $1(2 \%)$ & $20(40 \%)$ & $27(54 \%)$ & 3.40 \\
\hline 2 In my view, parents should be exemplary role models. & $1(2 \%)$ & $1(2 \%)$ & $15(30 \%)$ & $33(66 \%)$ & 3.60 \\
\hline 3 In my view, parents need to monitor their children's movements. & $2(4 \%)$ & $2(4 \%)$ & $18(36 \%)$ & $28(56 \%)$ & 3.40 \\
\hline 4 In my view, parents should treat their adult children as friends. & $2(4 \%)$ & $7(14 \%)$ & $14(28 \%)$ & $27(54 \%)$ & 3.30 \\
\hline $\begin{array}{l}\text { In my view, parents should get advisory and counseling services } \\
\text { from family and religious experts in educating children. }\end{array}$ & $2(4 \%)$ & $3(6 \%)$ & $21(42 \%)$ & $24(48 \%)$ & 3.30 \\
\hline
\end{tabular}

\section{Source: Questionnaire UKM-PP-05-FRGS0223-2010}

Respondents have suggestions for their respective families based on their experience of free mixing leading to out-ofwedlock pregnancy. The item with the highest score mean $=3.60$ shows that many among them wish their parents could be exemplary role models. This matter was emphasized by Abd. Hamid et al. (2001) in his study which found that parents need to be good examples to their children. If children are only taught with love without parents showing this loving attitude in all aspects of life, the effect would be the same as the crab telling its young to walk straight while the crab itself only shows walking sideways. Therefore, good examples by the parents need to be demonstrated in the moral education of their children. This matter was also emphasized in a study by Abd. Razak \& Nik Hussain (2007) regarding the method of educating children by parents behaving as exemplary role models. This is important because the character and personality of children in the future depends very much on moral education by parents at home.

In addition, this study finds that one of the roles a Muslim family can play to overcome this social ill is to provide adequate religious education to children. The majority of respondents (54\% or 27 persons) strongly agreed that their parents need to provide adequate religious education for them. This is because religious education from an early age will be a strong deterrent against immoral acts such as fornication. Islam strictly forbids fornication because it is a major sin cursed by Allah. It is also a despicable act with negative consequences which destroys social institutions. Fornication is despicable and shameful as stated by Allah in al-Qur'an (al-Isra': 32): "And come not near unto adultery (fornication). Lo! It is an abomination and an evil way".

Providing religious education is very important in teaching children to distinguish between what is beneficial and what is harmful. Al-Ghazali (2000), a renowned Muslim scholar stressed on religious education of children in his work Ihya' Ulum al-Din explained as follows: 
The method of training a child is one of the most important matters. A child is a trust given to parents. A child's heart is clean, pure like a precious jewel, free and clear of all kinds of engravings and impressions whatsoever. Children are open to accept any engravings on them and are inclined to any direction we wish them to. Thus, when accustomed to good qualities, a child will develop such qualities and will gain happiness in this world and hereafter. Parents, teachers and educators share in their happiness. On the contrary, when it is accustomed to despicable qualities and left to itself, it will perish and be wretched. Every responsibility in this matter rests on the shoulders of the caregiver or guardian. The guardian is obliged to protect the child from every sin, educate and teach it with nobleness of character while guarding it from mixing with mischievous friends.

This view clearly reflects that religious education in familiarizing children with virtuous conduct plays a positive role towards inculcating and preserving moral behaviour and altruistic motivation such as helping one another, tolerance, patience, honesty and obedience to Allah (Ali Shah, 2004). The importance of religious education for children is acknowledged by Western scholars such as Krauss et al., (2004) who stated that religion is a significant factor in adolescence. According to Krauss et al., (2004), religion may also be a bastion against the spread of substance abuse, crime, out-of-wedlock pregnancy, HIV infection, AIDs and so on.

Further, another role of the Muslim family in overcoming adolescent pregnancy is monitoring children's movements. The item "In my opinion, parents need to monitor their children's movements" has the same mean value as item "In my view, parents should provide religious education for thier children", that is, mean $=3.40$. This matter needs to be taken seriously by parents for them to identify children's activities in their absence at home. Parents also need to know who their children's friends are because friends tend to influence the future and behaviour of children. This matter is emphasized by the Prophet (pbuh):

From Abu Hurairah, The Prophet (pbuh) said: "A man follows the religion of his friend, so each one should consider whom he makes his friend". (Hadith narration by Abu Dawud)

Abd. Hamid et al. (2001) in his study entitled 'Senario Pendidikan Moral Masyarakat Melayu Zaman Teknologi Komunikasi Maklumat (ICT): Trend, Hala Tuju dan Model Pendidikan Moral Keluarga Islam (Scenario of Moral Education of the Malay Society in Information Communication Technology Era: Trend, Direction and Moral Educational Model of the Muslim Family) found that the influence of peers cannot be taken lightly in shaping the behavior and thinking of youth. Adolescents get involved in juvenile crime, breach of discipline, loitering and substance abuse partly due to inducement and encouragement from problematic peers. Lax parental control has caused the influence of peers to prevail thereby shaping the personality and attitudes of adolescents. Hence, parents must take heed in the issue of their children's peers. They must at least know who their friends are, where they go and with whom, for what purpose and so on. However, this is not the same as shackling children' movements and activities.

A number of respondents also suggest that the family institution, particularly parents, get advisory and counseling services from family and religious experts in educating children (mean=3.30). This view is in line with that of Sarnon et al. (2012) who in their study entitled "Hamil Luar Nikah: Memahami Remaja Sebagai Asas Intervensi Keluarga (Out-ofWedlock Pregnancy: Understanding Adolescence as a Basis for Family Intervention)" found that the counseling approach is needed to overcome the problem of pregnant unmarried adolescents through the technique of family intervention. This technique is applied to pregnant unmarried adolescents by ameliorating irrational emotional reaction of parents, and by focusing on how best to give physical and emotional support to the affected adolescent. When the crisis is resolved, the family may become more open-minded to explore available options and solve the problem.

\section{Conclusion}

Research results find that the family is one of the causes of unmarried adolescent pregnancy. A family with the characteristics of a communication gap between parents and adolescents that hinders closeness, parents' preoccupation with work leaving little time, attention and oversight for adolescents, liberal parents who give too much freedom in social mixing of daughters, parents who do not monitor adolescents' movements, domestic crisis, divorce and lack of religious education, is one of the factors which associates free mixing between sexes with adolescent girls leading to unwed pregnancy.

Further, this research finds that one of the roles a Muslim family can assume to deal with this social ill is to provide adequate religious education to children early in life with parents as exemplary role models, monitoring their social life, being aware of and concerned about peers they mix with, getting counseling services in educating adolescents, especially those who are unmarried pregnant girls. Research findings clearly show that the family needs to play their role 
in order to raise a happy family safe from adolescent moral decay and chronic social ills.

\section{Acknowledgement}

This study is financed by FRGS Research Group: UKM-PP-05-FRGS0223-2010; the Research Group of Arabic Culture and Islamic Civilization (KUKAPI, DPP-2014-068), UKM; the Action/Strategic Research Project (PTS-2012-061; PTS2014-068), UKM; the University-Industry Incentive Grant (INDUSTRI-2012-006), UKM; and the Arus Perdana Project (AP-2012-001; AP-2013-017; AP-2014-006), UKM.

\section{References}

Abd. Ghadur, Salamatussaadah \& Abdul Kadir, Nor Ba'yah. (2009). Hubungan romantik dan remaja hamil luar nikah di pusat pemulihan (Romantic relationships and unwed pregnant adolescents at rehabilitation centre). Jurnal e-Bangi, 1(4), 106-113.

Abd. Hamid, Mohd. Azhar, Suratman, Azmi Shah \& Othman, Muhamad Fauzi. (2001). Senario pendidikan moral masyarakat melayu zaman teknologi komunikasi maklumat (ICT): Trend, hala tuju dan model pendidikan moral keluarga Islam (Moral education scenario of Malay society in ICT era: Trend, direction and moral education model of muslim family). Jurnal Teknologi, 35(E) Dis, 45-70.

Abd. Razak, Ratna Roshida \& Nik Hussain, Nik Haslinda. (2007). Peranan institusi keluarga dalam penjagaan bangsa bertamadun (Role of family institution in safeguarding a civilized nation). Jurnal Kemanusiaan, 9(Jun), 73-82.

Alavi, Khadijah, Nen, Salina, Ibrahim, Fauziah, Md. Akhir, Noremy, Mohamad, Mohd Suhaimi \& Mohd Nordin, Noorhasliza. (2012). Hamil luar nikah di kalangan remaja (Out-of-wedlock pregnancy among adolescents). Journal of Social Sciences and Humanities, 7(1), 131-140.

Ali Mohamed, Ashgar Ali \& Sardar Baig, Farheen Baig. (2010). Prevention of baby dumping phenomenon: The Islamic perspective. Shariah Law Reports, 64-82.

Ali Shah, Ashiq. (2004). Self-religiosity, father's attitude and religious education in the moral behaviour of adolescents. Psychology Developing Societies, 16, 187-207.

Brandt, Carol L., Kane JR., Francis J. \& Moan, Charles A. (1978). Pregnant adolescents: Some psychosocial factors. Psychomatics, 19(12), 790-794.

Dev Raj, Acharya., Rabi, Bhattrai., Amudha, Poobalan., Edwin R, Van Teijlingen \& Glyn, Chapman. (2010). Factors associated with teenage pregnancy in South Asia: A systematic review. Health Science Journal, 4(1), 1-11.

al-Ghazali, Abu Hamid Muhammad bin Ahmad. (2000). Ihya' 'Ulum al-Din. Kaherah: Dar al-Taqwa li al-Turath.

Gliem, Joseph A. \& Gliem, Rosemary R. (2003). Calculating, interpreting and reporting alpha cronbach's realibility coefficient for likerttype scales. Midwest Research to Practice Conference in Adult, Continuing and Community Education, 82-88.

Jaudin, Rusilawati \& Shamsudin, Khadijah. (1995). Faktor-faktor risiko perilaku seks pra nikah remaja perempuan di Kuala Lumpur (Risk factors of pre-marital sexual behaviour of female adolescents in Kuala Lumpur). Jurnal Kesihatan Masyarakat, 1(12).

Krauss, Steven Eric, Azimi Hamzah, Turiman Suandi, Sidek Mohd Noah, Khairul Anwar Mastor, Rumaya Juhari, Jamiah Manap. (2004). The Islamic religiosity and religious personality index: towards understanding how Islamic religiosity among young Malaysian Muslims contributes to nation building. Prosiding Seminar Antarabangsa Pemikiran Islam. Jabatan Usuluddin dan Falsafah Universiti Kebangsaan Malaysia, Bangi, December 7-9.

Mahadi, Azizah. (2011). Pengalaman amalan seks bebas dalam kalangan remaja muslim di Rumah Bimbingan Remaja Puteri Raudhatus Sakinah, Sungai Buloh Selangor (Practice of free sex among Muslim adolescents of shelter home...). Prosiding Kolokium Siswazah, Fakulti Pengajian Islam 2011. Universiti Kebangsaan Malaysia, Bangi.

Mohd. Syamil \& Adriana Balqis. (2010). When Adultery to be A Culture. Kuala Lumpur: Mustread Sdn. Bhd.

Moore, Mignon R. (2001). Sexual intercourse and pregnancy among African American girls in high-poverty neighborhoods: The role of family and perceived community. Journal of Marriage and Family, 63, 1146-1157.

Petterson, Kjell I., Veenstra, Marijke., Guldvog, Bjorn \& Kolstad, Arne. (2004). The patient experiences questionnaire: Development, validity and reliability. International Journal for Quality in Health Care, 16(6), 453-463.

Purusothaman, Nirmala. (1997). Sikap dan corak dating pelajar-pelajar tingkatan lima di sebuah sekolah menengah yang terletak di pusat bandaraya Kuala Lumpur (Dating attitude and pattern of form five students of a secondary school in Kuala Lumpur city centre), Masters dissertation. Universiti Putra Malaysia, Serdang.

Sarnon, N., Mohamad, M. S, Fauziah, I, Alavi, K., Nen, S., Hoesni, S.M, Zaizul, R. \& Wan Azreena, J. (2012). Hamil luar nikah: Memahami remaja sebagai asas intervensi keluarga (Out-of-wedlock pregnancy: Understanding adolescents as a basis for family intervention). Journal of social Sciences and Humanities, 7 (1), 131-140.

Weisz, Monica G. \& Earls, Christopher M. (1995). The effects of exposure to filmed sexual violence on attitudes toward rape. Journal of Interpersonal Violence, 10(1), 71-84.

Yaakob, Ahmad Nawawi. (2005). Pendedahan seks di kalangan remaja institut pengajian tinggi dan remaja bandar (Sexual exposure among adolescents in higher institutes of learning and urban adolescents). Paper presented at Seminar Seksual Kebangsaan. Universiti Malaya, Kuala Lumpur, July 30. 